\title{
PERBANDINGAN PENGARUH KINERJA MANAJEMEN MUTU, MANAJEMEN PEMASARAN DAN AUDIT INTERNAL TERHADAP AKREDITASI PELAYANAN RUMAH SAKIT SWASTA DI PALEMBANG DAN PEKANBARU
}

\author{
Melia Frastuti $^{1}$ ) Muhni Pamuji ${ }^{2}$ ) Dwi Riana ${ }^{3}$ ) \\ 1) Fakultas Ekonomi Universitas Tridinanti Palembang, email: melia frastuti@univtridinanti.ac.id \\ 2) Fakultas Ekonomi Universitas Tridinanti Palembang, email: muhni_pamuji@univ-tridinanti.ac.id \\ 3) Fakultas Ekonomi Universitas Tridinanti Palembang, email: dwiriana@univ-tridinanti.ac.id
}

Abstract

Knowledge of hospital quality programs in Indonesia has many beneficial effects for patients and service providers. Improved quality has made perceptions about hospital services better in the patient's view, which in turn has resulted in increasing the use of hospital servi ces so that the income received by hospitals is increasing. Hospital Accreditation in Indonesia is carried out to assess hospital compliance with accreditation standards. Hospital accreditation that has been implemented since 1995 in Indonesia, so far uses accreditation standards based on what year the standard began to be used for assessment, so far there has never been a National Accreditation of Hospitals in Indonesia, while the accreditation status currently has national and international accreditation status. The National Hospital Accreditation Standards that are valid in 2018 include: patient safety goals, patient-focused goals, hospital management standards, and implementation of national programs, as well as integration of health education in hospital services. This study was aimed at investigating the effect of quality management, marketing management and internal auditing on private hospital service accreditation, taking a sample of 26 accredited private hospitals in Palembang and Pekanbaru by the Hospital Accreditation Commission (HAC). Data analysis was used to test hypotheses using Multiple Linear Regression analysis and Paired-Sample T-Test. The results of this study concluded that accreditation of private hospital services in Palembang and Pekanbaru was good, but the level of compliance from the management of private hospitals in Pekanbaru was higher, because of the 26 hospitals $61.5 \%$ were accredited while out of 28 private hospitals in Palembang only 50\% accredited by HAC.

Keywords: quality management, marketing management, internal audit and hospital service accreditation.

\begin{abstract}
Abstrak
Pengetahuan program mutu rumah sakit di Indonesia telah mengalami banyak perubahan yang menguntungkan pasien dan penyedia layanan. Mutu yang membaik telah membuat persepsi tentang layanan rumah sakit semakin bagus dalam pandangan pasien, yang selanjutnya mengakibatkan peningkatan penggunaan jasa rumah sakit sehingga pendapatan yang diterima rumah sakit semakin banyak. Akreditasi Rumah Sakit di Indonesia dilaksanakan untuk menilai kepatuhan rumah sakit terhadap standar akreditasi. Akreditasi rumah sakit yang sudah mulai dilaksanakan sejak tahun 1995 di Indonesia, selama ini menggunakan standar akreditasi berdasarkan tahun berapa standar tersebut mulai dipergunakan untuk penilaian, sehingga selama ini belum pernah ada Standar Nasional Akreditasi Rumah Sakit di Indonesia, sedangkan status akreditasi saat ini ada status akreditasi nasional dan status akreditasi internasional. Standar Nasional Akreditasi Rumah Sakit yang berlaku pada tahun 2018 berisi: sasaran keselamatan pasien, sasaran berfokus pasien, standar manajemen rumah sakit, dan pelaksanaan program nasional, serta integrasi pendidikan kesehatan dalam pelayanan rumah sakit. Penelitian ini di tujukan untuk menilai pengaruh kinerja manajemen mutu, manajemen pemasaran dan audit internal terhadap akreditasi pelayanan rumah sakit swasta, dengan mengambil jumlah sampel 26 rumah sakit swasta yang telah terakreditasi di Palembang dan Pekanbaru oleh Komisi Akreditasi Rumah Sakit (KARS). Analisis data yang digunakan untuk menguji hipotesis menggunakan analisis Regresi Linear Berganda dan Uji Beda PairedSample T-Test. Hasil penelitian ini diperoleh kesimpulan bahwa Akreditasi pelayanan rumah sakit swasta di Palembang dan Pekanbaru sudah baik, namun tingkat kepatuhan dari manajemen rumah sakit swasta di Pekanbaru lebih tinggi, karena dari 26 rumah sakit $61,5 \%$ terakreditasi sedangkan dari 28 rumah sakit swasta di Palembang hanya $50 \%$ terakreditasi oleh KARS.
\end{abstract}

Kata kunci: Manajemen Mutu, Manajemen Pemasaran, Audit Internal Dan Akreditasi Pelayanan Rumah Sakit. 


\section{PENDAHULUAN}

\begin{abstract}
Akreditasi Rumah Sakit adalah pengakuan pemerintah kepada rumah sakit yang telah memenuhi standar yang telah tetapkan. Tujuan umum akreditasi adalah untuk mendapatkan gambaran sejauh mana pemenuhan standar yang telah ditetapkan oleh rumah sakit-rumah sakit di Indonesia, sehingga mutu pelayanan rumah sakit dapat dipertanggungjawabkan. Akreditasi sangat bermanfaat baik bagi rumah sakit itu sendiri, masyarakat maupun pemilik rumah sakit. Akreditasi Rumah Sakit di Indonesia dilakukan oleh Komisi Akreditasi Rumah Sakit (KARS). Akreditasi rumah sakit merupakan salah satu cara untuk menilai mutu pelayanan rumah sakit. Peningkatan mutu pelayanan rumah sakit merupakan hal yang sangat penting, karena rumah sakit memberikan pelayanan yang paling kritis dan berbahaya dalam sistem pelayanan dan sasaran kegiatannya adalah jiwa manusia. (Kusbaryanto, 2010: 86)

Akreditasi Rumah Sakit di Indonesia dilaksanakan untuk menilai kepatuhan rumah sakit terhadap standar akreditasi. Akreditasi rumah sakit yang sudah mulai dilaksanakan sejak tahun 1995 di Indonesia, selama ini menggunakan standar akreditasi berdasarkan tahun berapa standar tersebut mulai dipergunakan untuk penilaian, sehingga selama ini belum pernah ada Standar Nasional Akreditasi Rumah Sakit di Indonesia, sedangkan status akreditasi saat ini ada status akreditasi nasional dan status akreditasi internasional, maka di Indonesia perlu ada Standar Nasional Akreditasi Rumah Sakit. Berdasarkan hal tersebut maka standar akreditasi untuk rumah sakit yang mulai diberlakukan pada Januari 2018 ini dikenal dengan Standar Nasional Akreditasi Rumah Sakit. (Snars, 2018: 6)
\end{abstract}

\section{KAJIAN PUSTAKA}

\section{a. Aspek Budaya dan Pembangunan Kesehatan}

Berikut ada empat faktor yang mempengaruhi kesehatan manusia, yaitu:

1. Keturunan, secara sederhana penyakit manusia dapat dibagi ke dalam beberapa penyebab. salah satunya adalah penyakit yang disebabkan oleh faktor gen. penyakit ini disebut juga sebagai penyakit herediter atau keturunan. Contohnya antara lain diabetes mellitus, albino, dan penyakit Wilson (penyakit kerusakan hati akibat penumpukan zat tembaga).

2. Layanan Kesehatan, beberapa aspek layanan kesehatan yang dapat mempengaruhistatuskesehatan individu pada khususnya dan masyarakat pada umumnya adalah: Tempat Layanan Kesehatan, Petugas Kesehatan, Biaya Kesehatan, dan Sistem Layanan Kesehatan.

3. Lingkungan, termasuk sosial budaya memberi pengaruh besar terhadap status kesehatan individu. Lingkungan adalah kombinasi antara kondisi fisik yang mencakup keadaan sumber daya alam serta flora dan fauna yang hidup di atas tanah maupun di dalam lautan. contohnya, ketersediaan air bersih, lingkungan hijau yang cukup, udara yang sehat dan bebas polusi.

4. Perilaku, dapat mempengaruhi status kesehatan. artinya, kondisi sehat atau sakit pada individu, keluarga, atau masyarakat dipengaruhi oleh prilaku yang bersangkutan. perilaku manusia bukan sesuatu yang berdiri sendiri, melainkan dipengaruhi oleh banyak faktor, seperti pendidikan, adat istiadat, kepercayaan, kebiasaan, sosial ekonomi dan sebagainya. (Putri, 2018:169-171)

Target kesehatan yang dilakukan oleh Kementerian Kesehatan Republik Indonesia dalam evaluasi paruh waktu Rencana Pembanguan Jangka Menengah Nasional (RPJMN) 2015-2019 telah ditetapkan 4 target utama kesehatan yang harus dicapai pada 2019. Keempat target tersebut, yakni meningkatkan status kesehatan dan gizi masyarakat, meningkatkan pengendalian penyakit menular dan tidak menular, meningkatkan pemerataan dan mutu pelayanan kesehatan, dan meningkatkan perlindungan finansial, ketersediaan, penyebaran, mutu obat serta sumber daya kesehatan. 
Melia, Muhni \& Pamuji, perbandingan pengaruh kinerja manajemen mutu, manajemen pemasaran dan audit internal terhadap ....

\section{b. Kinerja Manajemen Mutu Rumah Sakit}

Rumahsakitseyogianya

mempertimbangkan bahwa asuhan dirumah sakit merupakan bagian dari suatu sistem pelayanan yang terintegrasi dengan para profesional pemberi asuhan dan tingkat pelayanan yang akan membangun suatu kontinuitas pelayanan. Maksud dan tujuannya adalah menyelaraskan kebutuhan asuhan pasien dengan pelayanan yang sudah tersedia di rumah sakit, mengkoordinasikan pelayanan, kemudian merencanakan pemulangan dan tindakan selanjutnya. Sebagai hasilnya adalah meningkatkan mutu asuhan pasien dan efisiensi penggunaan sumber daya yang tersedia di rumah sakit. (SNARS, 2018: 57)

Sebagai contoh dalam Tata Kelola Sistem Informasi Manajemen Rumah Sakit yang bermutu struktur organisasi rumah sakit harus memiliki unit/ instalasi informasi dan teknologi yang terdiri dari:

1. Kepala Instalasi SIMRS

2. Staf informasi dan teknologi Fungsional Sumber Daya Manusia informasi dan teknologi Sumber daya manusia informasi dan teknologi terdiri dari staf yang memiliki kualifikasi dalam bidang:

\section{Staf Analis System}

2. Staf Programmer

3. Staf Hardware

4. Staf Maintanance Jaringan

Kemudian Kerangka Kerja Tata Kelola Informasi Dan Teknologi Sangat di rekomendasikan menggunakan kerangka kerja yang best practice seperti cobit. (Peraturan Menteri Kesehatan RI Nomor 82 Tahun 2013, Bab IV)

Menurut Herjanto (2008: 394) ada lima dimensi yang menjadi perhatian dalam hal mutu jasa, sebagai berikut :

1. Keandalan, yaitu kemampuan melaksanakan jasa yang dijanjikan secara akurat dan cepat.

2. Responsif, yaitu kemauan untuk membantu pelanggan dan memberikan jasa yang sesuai dengan harapan pelanggan.

3. Bentuk nyata, yaitu fasilitas fisik, peralatan dan penampilan personal.

4. Jaminan, yaitu pengetahuan dan sikap pegawai serta kemampuan mereka untuk menunjukkan kepercayaan, keyakinan dan kesopanan.

5. Empati, yaitu perhatian individual yang diberikan kepada pelanggan.
Proses bisnis dalam manajemen rumah sakit memiliki dua pelayanan yang berbeda namun saling berkaitan satu sama lainnya yaitu:

1. Pelayanan Utama (Front Office)

Setiap Rumah Sakit memiliki prosedur yang unik (berbeda satu dengan lainnya), tetapi secara umum/ generik memiliki prosedur pelayanan terintegrasi yang sama yaitu proses pendaftaran, proses rawat (jalan atau inap) dan proses pulang. Data yang dimasukan pada proses rawat akan digunakan pada proses rawat dan pulang.

2. Pelayanan Administratif (Back-Office) Rumah sakit merupakan unit yang mengelola sumber daya fisik (manusia, uang, mesin/ alat kesehatan/ aset, material seperti obat, reagen, alat tulis kantor, barang habis pakai dan sejenisnya). Walaupun proses bisnis setiap Rumah sakit unik tapi tetap terdapat proses umum, diantaranya perencanaan, pembelian/ pengadaan, pemeliharaan stok/ inventory, pengelolaan Aset, pengelolaan Sumber Daya Manusia, pengelolaan uang (hutang, piutang, kas, buku besar dan lainnya). Proses back office ini berhubungan/ link dengan proses pada front office. (Lampiran Peraturan Menteri Kesehatan RI Nomor 82 Tahun 2013: 8-9)

\section{Sistem Informasi Manajemen Rumah} Sakit

Persoalan penting ketika mengembangkan sebuah layanan baru atau mengubah layanan yang sudah ada adalah apa perbedaan antara layanan baru dibandingkan dengan layanan yang ditawarkan oleh perusahaan saat ini. Berikut adalah tiga faktor umum yang perlu dipertimbangkan ketika menentukan hal tersebut:

1. Kesamaan dengan layanan yang dijalankan saat ini. Artinya layanan baru harus sesuai dengan layanan pelanggan yang dijalankan saat ini.

2. Kesamaan dengan proses yang dijalankan saat ini. gagasan yang sangat luar biasa pun terkait layanan membutuhkan dukungan operasional agar dapat terlaksana.

3. Pertimbangan finansial. Pendesaian dan implementasi sebuah pelayanan baru memakan biaya dan harus 
dipertimbangkan secara finansial. Meskipun pendesaian dan implementasi sebuah pelayanan barusering dianggap hal positif yang akan mendatangkan keuntungan, hal tersebut dapat juga hanya sekedar layanan baru supaya tidak kehilangan para pelanggan yang penting. (Jacobs, 2015: 69)

Banyak sekali keuntungan yang bisa dirasakan apabila kita mempunyai sebuah jaringan komputer, diantaranya adalah sebagai berikut:

4. Menghemat biaya

Dengan adanya jaringan komputer, para user atau pengguna komputer dapat menekan biaya untuk kebutuhan perangkat operasional, karena peralatan yang ada, bisa dibagi dan digunakan secara bersama-sama.

5. Mempercepat proses data sharing (berbagi data)

Dengan adanya jaringan komputer, transfer data akan lebih cepat dan bahkan dapat menjangkau jarak, yang jangkauannya cukup luas. Hal tersebut dapat mempermudah pengguna utuk mendapatkan file data yang diperlukan.

6. Menjaga informasi tetap Up-To Date dan berkualitas

Dengan kita membuat sebuah jaringan komputer, maka memungkinkan sistem penyimpanan data menjadi terpusat, serta dapat dikelola dengan sangat baik. Data dikelola oleh komputer server, maka pengguna dapat mengakses data dari berbagai tempat yang berbeda dan juga dapat membatasi akses ke data tertentu. (Hakam, 2016: 40)

\section{Kinerja Manajemen Pemasaran Rumah Sakit}

Menurut Kotler (2009: 115) pemasar harus menyatakan tujuan saluran mereka berdasarkan tingkat hasil jasa yang ditargetkan. Dalam kondisi yang kompetitif, institusi saluran harus mengatur tugas fungsional mereka untuk meminimalkan total biaya saluran, namun tetap menyediakan tingkat output jasa yang diinginkan. Biasanya perencana dapat mengidentifikasi beberapa segmen pasar yang menginginkan tingkat jasa berbeda. Dalam melakukan perencanaan efektif, diperlukan penentuan segmen pasar yang akan dilayani dan memilih saluran terbaik untuk masing masing segmen tersebut.

Dalam SNARS (2018: 44) kebijakan promosi akreditasi yaitu setelah rumah sakit menerima pemberitahuan resmi tentang hasil akreditasi, rumah sakit dapat mempublikasikan capaian status akreditasinya. Informasi mengenai status akreditasi rumah sakit akan dicantumkan dalam situs web KARS (www.kars.or.id). Situs web tersebut dapat diakses oleh setiap orang untuk mengetahui rumah sakit yang telah terakreditasi oleh KARS.

\section{Kinerja Audit Internal Sebagai Fungsi Pengawasan Rumah Sakit}

Pemeriksaan(auditing)menurut

Satrianegara (2014: 179) adalah pemeriksaan keuangan perusahaan yang menyangkut pemeriksaan laporan keuangan, harta perusahaan, harta piutang perusahaan, dan sebagainya untuk diperiksakan kelengkapan dan kebenarannya. Untuk memberikan kepastian bahwa harta modal perusahaan dikelola dengan baik. Dengan pemeriksaan keuangan ini untuk selanjutnya ditelusuri sekaligus manajemennya. Jadi pada audit dimulai dari bagian keuagan kemudian ke operasional perusahaan, yaitu meliputi

prosedur keuangan, fasilitas fisik, kebijaksanaan, program penggunaan wewenang, prosedur, dan metode operasi.

Proses pengawasan biasanya terdiri atas lima tahap menurut Korompis (2016: 120) berikut penjelasannya:

1. Penetapan standar pelaksanaan
(perencanaan) Mengandung arti suatu kesatuan pengukuran yang dapat digunakan sebagai patokan untuk penilaian hasil. Tujuan, sasaran, kuota, dan target pelaksanaan dapat digunakan sebagai standar.

2. Penentuan pengukuran pelaksanaan kegiatan. Beberapa pertanyaan yang penting digunakan adalah sebagai berikut:

a. Berapa kali (how often) pelaksanaan seharusnya diukur? apakah setiap jam, hari, minggu atau bulan.

b. Apa bentuk (what form) pengukuran yang akan dilakukan? 
Melia, Muhni \& Pamuji, perbandingan pengaruh kinerja manajemen mutu, manajemen pemasaran dan audit internal terhadap ....

c. apakah laporan tertulis, inspeksi visual atau telepon.

d. Siapa (who) yang akan terlibat? Apakah manajer, staf atau departemen?

3. Pengukuran pelaksanaan kegiatan

Cara yang dapat dilakukan untuk pengukuran pelaksanaan, yaitu pengamatan (observasi), laporan (lisan dan atau tertulis), metode otomatis, dan inspeksi, pengujian (tes), atau pengambilan sampel.

4. Perbandingan pelaksanaan dengan standar dan analisis penyimpangan

tahap kritis dari proses pengawasan adalah perbandingan pelaksanaan nyata dengan pelaksanaan yang direncanakan atau standar yang telah ditetapkan. walaupun tahap ini paling mudah dilakukan, tetapi kompleksitas dapat terjadi pada saat menginterpretasikan adanya penyimpangan atau deviasi.

5. Pengambilan tindakan koreksi, jika perlu. KERANGKA PEMIKIRAN
Tindakan koreksi dapat dilakukan dalam berbagai bentuk. Standar dapat diubah, pelaksanaan diperbaiki, atau keduanya dilakukan bersamaan. tindakan koreksi dapat berupa:

a. Merubah standar awal (mungkin terlalu tinggi atau terlalu rendah).

b. Mengubah pengukuran pelaksanaan (inspeksi terlalu sering atau kurang atau bahkan mengganti sistem pengukuran itu sendiri).

c. Mengubah cara dalam menganalisis dan menginterpretasikan penyimpangan.

Audit program kesehatan terbagi menjadi dua bagian yaitu audit laporan keuangan dan audit kinerja kesehatan (Bastian 2008: 286-290), audit laporan keuangan hasilnya adalah kewajaran dari suatu laporan keuangan organisasi, maka untuk audit kineja kesehatan non keuangan ada tiga kriteria pengukuran yang penting yaitu ekonomis, efisien dan efektif.

Gambar 2.2 yang menyajikan Kerangka Penelitian ini sebagai berikut: 
Journal of Applied Business Administration Vol 2, No 2,September 2018, hlm. 278-293

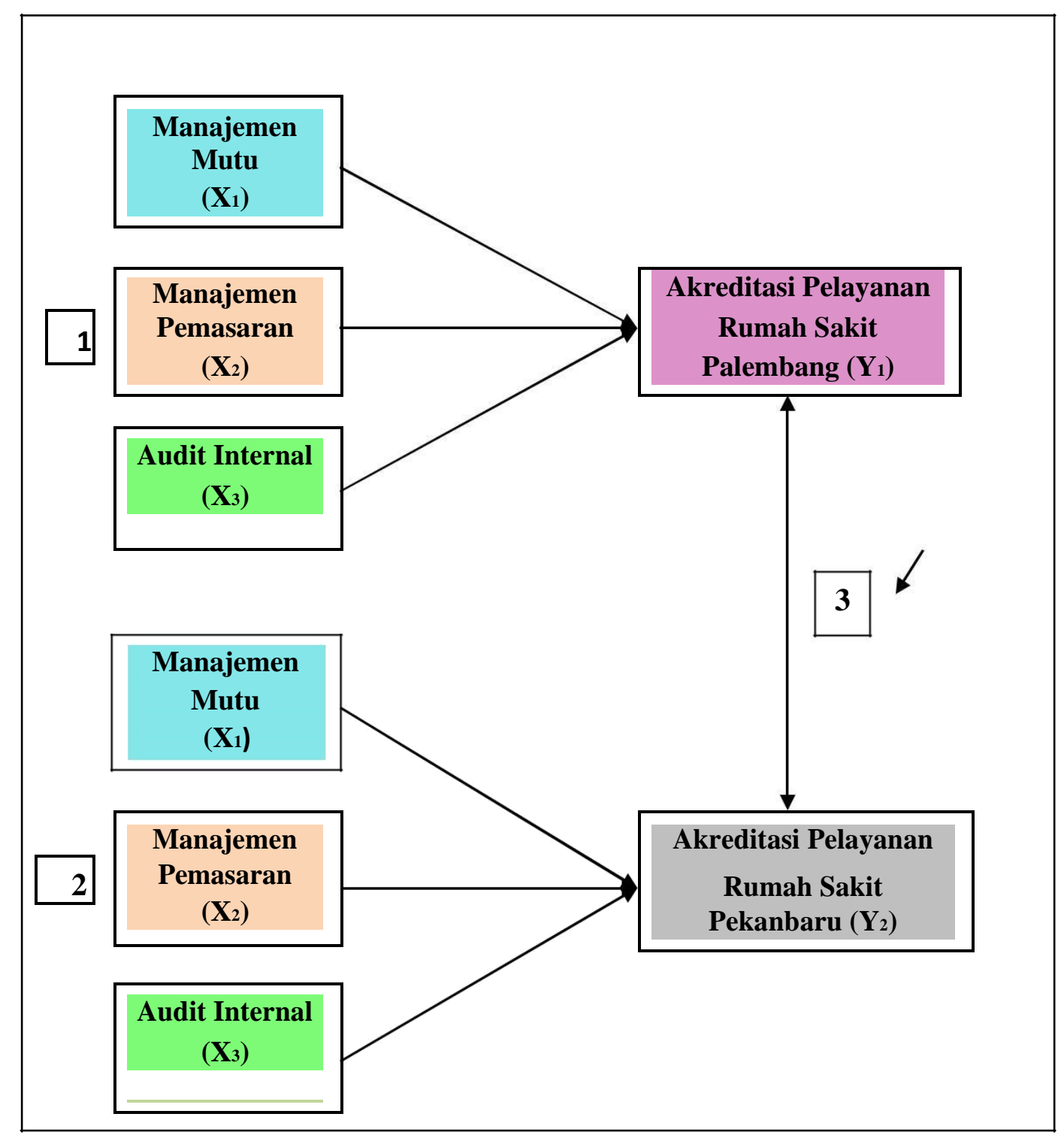

Gambar 2.2

Kerangka Pemikiran 
Melia, Muhni \& Pamuji, perbandingan pengaruh kinerja manajemen mutu, manajemen pemasaran dan audit internal terhadap ....

\section{HIPOTESIS PENELITIAN}

Hipotesis yang ingin diharapkan dalam penelitian ini dapat dijabarkan sebagai berikut:

1. Kinerja manajemen mutu dalam meningkatkan akreditasi pelayanan rumah sakit di Palembang berpengaruh positif.

2. Kinerja manajemen pemasaran dalam meningkatkan akreditasi pelayanan rumah sakit di Palembang bepengaruh positif.

3. Kinerja audit internal dalam meningkatkan akreditasi pelayanan rumah sakit di Palembang berpengaruh positif.

4. Kinerja manajemen mutu, manajemen pemasaran dan audit internal dalam meningkatkan akreditasi pelayanan rumah sakit di Palembang berpengaruh positif.

5. Kinerja manajemen mutu dalam meningkatkan akreditasi pelayanan rumah sakit di Pekanbaru berpengaruh positif.

6. Kinerja manajemen pemasaran dalam meningkatkan akreditasi pelayanan rumah sakit di Pekanbaru berpengaruh positif.

7. Kinerja audit internal dalam meningkatkan akreditasi pelayanan rumah sakit di Pekanbaru berpengaruh positif.

8. Kinerja manajemen mutu, manajemen pemasaran dan audit internal dalam meningkatkan akreditasi pelayanan rumah sakit di Pekanbaru berpengaruh positif.

9. Akreditasi pelayanan rumah sakit swasta di Palembang dan Pekanbaru tidak ada perbedaan, artinya sama-sama baik.

\section{METODELOGI}

\section{a. Lokasi Penelitian}

Penelitian ini dilakukan di rumah sakit swasta yang ada di Kota Palembang dan Kota Pekanbaru.

\section{b. Waktu Penelitian}

Penelitian ini dilaksanakan pada bulan Maret hingga Oktober tahun 2018.

\section{c. Populasi}

Populasi adalah wilayah generalisasi yang terdiri atas obyek/ subyek yang mempunyai kualitas dan karakteristik tertentu yangditetapkan oleh peneliti untuk dipelajari dan kemudian ditarik kesimpulan (Sugiyono, 2012: 80). Sedangkan menurut Hasan (2008: 88) populasi adalah totalitas dari semua objek atau individu yang memiliki karekteristik tertentu, jelas dan lengkap yang akan diteliti (bahan penelitian). Objek atau nilai disebut unit analisis atau elemen populasi. unit analisis berupa orang, perusahaan, hasil produksi, rumah tangga dan tanah pertanian.

Penelitian ini mengambil populasi seluruh rumah sakit swasta yang ada di Kota Palembang terdiri dari 28 (dua puluh delapan) rumah sakit, yang tergolong atas 8 rumah sakit dengan status akreditasi Tingkat Paripurna, 1 rumah sakit dengan status akreditasi Tingkat Utama, 5 rumah sakit dengan status akreditasi Lulus Perdana sedangkan rumah sakit 14 belum berakreditasi. Berikut daftar rumah sakit swasta di Kota Palembang pada tabel 3.1, yaitu: 
Tabel 3.1

Nama Rumah Sakit Swasta, Kelas, Penyelenggara, Status Akreditasi dan Rating di Kota Palembang

\begin{tabular}{|c|c|c|c|c|c|}
\hline No & Nama Rumah Sakit & Kelas & Penyelenggara & Status Akreditasi & $\begin{array}{c}\text { Rating } \\
\text { (Bintang) }\end{array}$ \\
\hline 1 & RS Islam Siti Khadijah & B & Yayasan Islam Siti Khadijah & Tingkat Paripurna & \\
\hline 2 & RSU RK Charitas & B & RS RK Charitas & Tingkat Paripurna & \\
\hline 3 & RSU Siloam Sriwijaya & C & $\begin{array}{l}\text { PT RS Siloam Hospitals } \\
\text { Sumsel }\end{array}$ & Tingkat Paripurna & $\vec{n}$ \\
\hline 4 & RSU Dr. AK. Gani & $\mathrm{C}$ & $\begin{array}{l}\text { KESDAM II Sriwijaya TNI } \\
\text { AD }\end{array}$ & Tingkat Paripurna & तैs \\
\hline 5 & RSU Pertamina & $\mathrm{C}$ & $\begin{array}{c}\text { PT Pertamina Bina Medika } \\
\text { Palembang }\end{array}$ & Tingkat Paripurna & ș \\
\hline 6 & RSU Muhammadiyah & $\mathrm{C}$ & $\begin{array}{c}\text { Pimpinan Wilayah } \\
\text { Muhammadiyah Sumsel }\end{array}$ & Tingkat Paripurna & 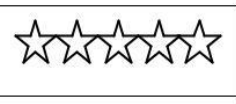 \\
\hline 7 & RS Bhayangkara & $\mathrm{C}$ & Polda Sumsel & Tingkat Paripurna & 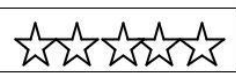 \\
\hline 8 & RSU Myria & $\mathrm{C}$ & $\begin{array}{l}\text { Yayasan Charitas } \\
\text { Palembang }\end{array}$ & Tingkat Paripurna & 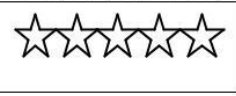 \\
\hline 9 & RSU Pusri Palembang & $\mathrm{C}$ & PT Graha Pusri Medika & $\begin{array}{c}\text { Tingkat } \\
\text { Utama }\end{array}$ & 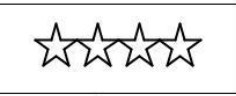 \\
\hline 10 & RSU Bunda & $\mathrm{C}$ & Yayasan Bunda Palembang & Lulus Perdana & $\Sigma$ \\
\hline 11 & $\begin{array}{l}\text { RS Ibu dan Anak } \\
\text { YK Madira }\end{array}$ & $\mathrm{C}$ & YK Madira Palembang & Lulus Perdana & $\hat{L}$ \\
\hline 12 & RSU Pelabuhan & $\mathrm{D}$ & PT RS Pelabuhan & Lulus Perdana & $\hat{\omega}$ \\
\hline 13 & RS Karya Asih Charitas & $\mathrm{D}$ & Yayasan Karya Asih & Lulus Perdana & 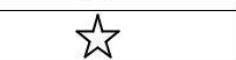 \\
\hline 14 & $\begin{array}{l}\text { RS Ibu dan Anak Bunda } \\
\text { Noni }\end{array}$ & $\mathrm{C}$ & PT Noni Wiruan Juni & Lulus Perdana & $\underline{\sim}$ \\
\hline 15 & RSU Ar Rasyid & $\mathrm{C}$ & $\begin{array}{l}\text { KOL. CKM (P). dr. Toni } \\
\text { Siguntang, Sp.THT }\end{array}$ & Belum ditetapkan & - \\
\hline 16 & $\begin{array}{l}\text { RS Ibu dan Anak Az } \\
\text { Zahra }\end{array}$ & $\mathrm{C}$ & Yayasan Pintu Ilmu & Belum ditetapkan & - \\
\hline 17 & RSU Hermina & $\mathrm{C}$ & PT Medikaloka Palembang & $\begin{array}{c}\text { Proses } \\
\text { (Sudah berakhir } \\
01 / 05 / 2018 \text { ) }\end{array}$ & - \\
\hline 18 & $\begin{array}{l}\text { RS Ibu dan Anak Kader } \\
\text { Bangsa }\end{array}$ & $\mathrm{C}$ & Yayasan Kader Bangsa & Belum ditetapkan & - \\
\hline 19 & $\begin{array}{l}\text { RS Ibu dan Anak } \\
\text { Marissa }\end{array}$ & $\mathrm{C}$ & Yayasan Marisa & Belum ditetapkan & - \\
\hline 20 & RSU Sriwijaya & $\mathrm{C}$ & PT Ryanhana Medika & Belum ditetapkan & - \\
\hline 21 & RSU Graha Mandiri & $\mathrm{D}$ & PT Karya Mandiri Abadi & Belum ditetapkan & - \\
\hline
\end{tabular}


Melia, Muhni \& Pamuji, perbandingan pengaruh kinerja manajemen mutu, manajemen pemasaran dan audit internal terhadap ....

Tabel 3.1 Lanjutan

Nama Rumah Sakit Swasta, Kelas, Penyelenggara, Status Akreditasi dan Rating di Kota Palembang

\begin{tabular}{|c|c|c|c|c|c|}
\hline No & Nama Rumah Sakit & Kelas & Penyelenggara & Status Akreditasi & $\begin{array}{c}\text { Rating } \\
\text { (Bintang) }\end{array}$ \\
\hline 22 & $\begin{array}{l}\text { RS Ibu dan Anak } \\
\text { Tiara Fatrin }\end{array}$ & $\mathrm{C}$ & $\begin{array}{c}\text { dr.Nurul Komariah AS, } \\
\text { MARS }\end{array}$ & $\begin{array}{c}\text { Proses } \\
\text { (Berlaku sejak } \\
16 / 07 / 2012\end{array}$ & - \\
\hline 23 & $\begin{array}{l}\text { RS Ibu dan Anak } \\
\text { Rika Amelia }\end{array}$ & $\bar{C}$ & Yayasan Rika Amelia & Belum ditetapkan & - \\
\hline 24 & $\begin{array}{l}\text { RSU Musi Medika } \\
\text { Cendikia }\end{array}$ & $\mathrm{C}$ & $\begin{array}{c}\text { dr Yudhi } \\
\text { Fadhilah.SpPD.KKV.FINASIM.M } \\
\text { ARS }\end{array}$ & Belum ditetapkan & - \\
\hline 25 & $\begin{array}{l}\text { RS Ibu dan Anak } \\
\text { Widiyanti }\end{array}$ & $\mathrm{C}$ & Yayasan Widiyanti & Belum ditetapkan & - \\
\hline 26 & $\begin{array}{l}\text { RS Ibu dan Anak } \\
\text { Mama }\end{array}$ & - & dr.Hariya Romiza,Sp.OG & Belum ditetapkan & - \\
\hline 27 & $\begin{array}{l}\text { RS Ibu dan Anak } \\
\text { Trinanda }\end{array}$ & - & $\begin{array}{l}\text { PT. Maya Sari Nahdifa } \\
\text { Husada Bakti }\end{array}$ & Belum ditetapkan & - \\
\hline 28 & $\begin{array}{l}\text { RS Khusus Bedah } \\
\text { Medika Insani }\end{array}$ & - & $\begin{array}{l}\text { PT. Surgika Medika Insani } \\
\text { Palembang }\end{array}$ & Belum ditetapkan & - \\
\hline
\end{tabular}

Sumber: Komisi Akreditasi Rumah Sakit (KARS), dan data olahan sekunder tahun 2018

Untuk Kota Pekanbaru terdiri dari 26 (dua puluh enam) rumah sakit, yang tergolong atas 7 rumah sakit dengan status akreditasi Tingkat Paripurna, 1 rumah sakit dengan status akreditasi Tingkat Utama, 8 rumah sakit dengan status akreditasi Lulus Perdana sedangkan rumah sakit 10 belum berakreditasi. Untuk daftar rumah sakit swasta di Pekanbaru dapat dilihat pada tabel 3.2 berikut:

Tabel 3.2

Nama Rumah Sakit Swata, Kelas, Penyelenggara, Status Akreditasi dan Rating di Kota Pekanbaru

\begin{tabular}{|r|l|c|c|c|c|}
\hline No & Nama Rumah Sakit & Kelas & Penyelenggara & Status Akreditasi & $\begin{array}{c}\text { Rating } \\
\text { (Bintang) }\end{array}$ \\
\hline 1 & RSU Awal Bros Pku & B & PT Awal Bros Putra Medika & Tingkat Paripurna \\
\hline 2 & RSU Santa Maria & B & Yayasan Salus Infirm & Tingkat Paripurna \\
\hline 3 & RSU Eka Hospital & B & PT Ekamas Internasional & Tingkat Paripurna \\
\hline 4 & RSU Islam Ibnu Sina & B & PT Shifa Utama & Tingkat Paripurna \\
\hline 5 & RSU Awal Bros Panam & C & PT Awal Bros Karya Medika & Tingkat Paripurna \\
\hline 6 & RSU Syafira & C & PT Dianra Kartika Nasir & Tingkat Paripurna \\
\hline 7 & RSU Prima Hospital & C & PT Riau Anggun Mandiri & Tingkat Paripurna \\
\hline
\end{tabular}


Tabel 3.2 Lanjutan

Nama Rumah Sakit Swata, Kelas, Penyelenggara, Status Akreditasi dan Rating di Kota Pekanbaru

\begin{tabular}{|c|c|c|c|c|c|}
\hline No & Nama Rumah Sakit & Kelas & Penyelenggara & Status Akreditasi & $\begin{array}{c}\text { Rating } \\
\text { (Bintang) }\end{array}$ \\
\hline 8 & $\begin{array}{l}\text { RS Ibu dan Anak } \\
\text { Zainab }\end{array}$ & C & PT Fatimah Azzahra & Tingkat Utama & 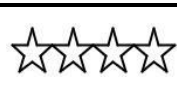 \\
\hline 9 & RSU Bina Kasih & $\bar{C}$ & PT Bina Kasih & Lulus Perdana & 交 \\
\hline 10 & $\begin{array}{l}\text { RSU Khusus mata } \\
\text { SMEC Pekanbaru }\end{array}$ & $\bar{C}$ & PT Sumatra Cahaya Mandiri & Lulus Perdana & $\hat{\sim}$ \\
\hline 11 & $\begin{array}{l}\text { RSU TNI AU- } \\
\text { LANUD Roesmin } \\
\text { Nurjadin }\end{array}$ & $\mathrm{C}$ & TNI AU & Lulus Perdana & $\hat{\sim}$ \\
\hline 12 & $\begin{array}{l}\text { RSU Bhayangkara } \\
\text { Pekanbaru Polda Riau }\end{array}$ & $\mathrm{C}$ & Polda Riau & Lulus Perdana & $\hat{\imath}$ \\
\hline 13 & RSU Prof Dr Tabrani & $\bar{C}$ & PT Tabrani & Lulus Perdana & $\hat{\sim}$ \\
\hline 14 & RSU Sansani & $\mathrm{C}$ & PT Sansani Barokah Sentosa & Lulus Perdana & 孛 \\
\hline 15 & RSU Tk IV Pekanbaru & D & TNI AD & Lulus Perdana & $\dot{s}$ \\
\hline 16 & $\begin{array}{l}\text { RSU Awal Bros } \\
\text { Ahmad Yani }\end{array}$ & $\mathrm{D}$ & PT Perdana Utama Mandiri & Lulus Perdana & 勾 \\
\hline 17 & RS Aulia Hospital & $\mathrm{C}$ & Nurzahedi/ Eddi Tanjung & $\begin{array}{c}\text { Proses (karena } \\
\text { baru berdiri) }\end{array}$ & - \\
\hline 18 & RS JMB Pekanbaru & $\mathrm{C}$ & Depsi Indri P. Simanjuntak & Belum ditetapkan & - \\
\hline 19 & RS Lancang Kuning & $\mathrm{C}$ & Drs. Anwar Rahman & Belum ditetapkan & - \\
\hline 20 & $\begin{array}{l}\text { RS Pekanbaru Medical } \\
\text { Center (PMC) }\end{array}$ & $\mathrm{C}$ & PT Pekanbaru Medika & Belum ditetapkan & - \\
\hline 21 & $\begin{array}{l}\text { RS Ibu dan Anak } \\
\text { Andini }\end{array}$ & $\mathrm{C}$ & $\begin{array}{c}\text { Direktur: } \\
\text { dr. Retno Putri, M. Kes }\end{array}$ & Belum ditetapkan & - \\
\hline 22 & $\begin{array}{l}\text { RS Ibu dan Anak } \\
\text { Budi Mulia }\end{array}$ & $\bar{C}$ & dr. Budi Mulia, Sp.OG & Belum ditetapan & - \\
\hline 23 & $\begin{array}{l}\text { RS Ibu dan Anak } \\
\text { Eria Bunda }\end{array}$ & $\mathrm{C}$ & $\begin{array}{l}\text { dr. Emdahril Muchtar, } \\
\text { Sp.OG dan rekan }\end{array}$ & Belum ditetapkan & - \\
\hline 24 & $\begin{array}{l}\text { RS Khusus Mata } \\
\text { Pekanbaru Eye Center }\end{array}$ & $\mathrm{C}$ & $\begin{array}{c}\text { Direktur: } \\
\text { Dr. Yasri, Sp.M }\end{array}$ & Belum ditetapkan & - \\
\hline 25 & RS Bersalin Annisa & $\mathrm{C}$ & PT Kartini Bangun & Belum ditetapkan & - \\
\hline 26 & RS Universitas Riau & $\mathrm{D}$ & $\begin{array}{c}\text { Universitas Riau } \\
\text { Direktur : } \\
\text { dr. Zulharman, M. Med.Ed }\end{array}$ & Belum ditetapkan & - \\
\hline
\end{tabular}

Sumber: Komisi Akreditasi Rumah Sakit (KARS), dan data olahan sekunder tahun 2018 
Melia, Muhni \& Pamuji, perbandingan pengaruh kinerja manajemen mutu, manajemen pemasaran dan audit internal terhadap ....

\section{d. Sampel}

Menurut Sugiyono (2012: 81), sampel adalah bagian dari jumlah dan karakteristik yang dimiliki oleh populasi tersebut. Pada penelitian ini sampel yang diambil dari populasi menggunakan purposive sampling. Purposive sampling adalah teknik pengambilan data dengan pertimbangan tertentu (Sugiyono, 2012: 218).

Jenis sampel yang digunakan adalah sampel sampling berlapis (sampling stratified). Menurut Hasan (2008: 88) sampling berlapis adalah bentuk sampling random yang populasinya atau elemen populasinya dibagi dalam kelompok-kelompok yang disebut strata. Sampling stratified dilakukan apabila:

1. Elemen- elemen populasi heterogen.

2. Ada kriteria yang akan dipegunakan sebagai dasar untuk menstratifikasi populasi ke dalam stratum-stratum, misalnya variabel yang akan diteliti.

3. Adanya data pendahuluan dari populasi mengenai criteria yang akan digunakan untuk stratifikasi.

4. Dapat diketahui dengan tepat jumlah satuan-satuan individu dari setiap stratum dalam populasi.

Proses pengerjaannya sebagai

berikut: Hasan (2008: 88)

1. Membagi populasi menjadi beberapa stratum.
2. Mengambil sebuah sampel random dari tiap stratum. Banyaknya unsur yang dipilih dari setiap stratum bolehsebandingatautidak sebanding dengan jumlah stratum dalam populasinya. Jika pengambilan banyaknya unsur tiap stratum sebanding dengan ukuranukuran tiap stratum dan pengambilannya dilakukan secara random, dinamakan proportional random sampling.

3. Menggabungkan hasil dari pengambilan sampel tiap stratum, menjadi satu sampel yang diperlukan.

Kriteria yang digunakan dalam penelitian ini yaitu: Rumah sakit swasta yang telah berakreditasi pada data Komisi Akreditasi Rumah sakit (KARS) Tahun 2018. Untuk rumah sakit di Palembang sebanyak 13 (tiga belas) unit dan 13 (tiga belas) unit rumah sakit di Pekanbaru dimana mengambil persamaan tipe rumah sakit yaitu rumah sakit yang berakreditasi Tingkat Paripurna berjumlah 7 (tujuh) rumah sakit, rumah sakit berakreditasi Tingkat Utama ada 1 (satu) rumah sakit, dan 5 (lima) rumah sakit berakreditasi Lulus Perdana. Berikut daftar rumah sakit swasta di Palembang dan Pekanbaru yang dijadikan sampel penelitian dalam Tabel 3.3 dan Tabel 3.4, yaitu:

Tabel 3.3

13 Rumah Sakit Swasta di Kota Palembang yang dijadikan sampel

\begin{tabular}{|c|l|c|}
\hline No & \multicolumn{1}{|c|}{ Nama Rumah Sakit } & Status Akreditasi \\
\hline 1 & RS Islam Siti Khadijah & Tingkat Paripurna \\
\hline 2 & RSU RK Charitas & Tingkat Paripurna \\
\hline 3 & RSU Siloam Sriwijaya & Tingkat Paripurna \\
\hline 4 & RSU Dr. AK. Gani & Tingkat Paripurna \\
\hline 5 & RSU Pertamina & Tingkat Paripurna \\
\hline
\end{tabular}




\begin{tabular}{|c|l|c|}
\hline 6 & RSU Muhammadiyah & Tingkat Paripurna \\
\hline 7 & RS Bhayangkara & Tingkat Paripurna \\
\hline 8 & RSU Pusri Palembang & Tingkat Utama \\
\hline 9 & RSU Bunda & Lulus Perdana \\
\hline 10 & RS Ibu dan Anak YK Madira & Lulus Perdana \\
\hline 11 & RSU Pelabuhan & Lulus Perdana \\
\hline 12 & RS Karya Asih Palembang & Lulus Perdana \\
\hline 13 & RS Ibu dan Anak Bunda Noni & Lulus Perdana \\
\hline
\end{tabular}

Sumber: data olahan sekunder, tahun 2018

Untuk 13 sampel rumah sakit swasta di Kota Pekanbaru dalam penelitian ini sebagai berikut:

Tabel 3.4

13 Rumah Sakit Swasta di Kota Pekanbaru yang dijadikan sampel

\begin{tabular}{|c|l|c|}
\hline No & \multicolumn{1}{|c|}{ Nama Rumah Sakit } & Status Akreditasi \\
\hline 1 & RSU Awal Bros Pekanbaru & Tingkat Paripurna \\
\hline 2 & RSU Santa Maria & Tingkat Paripurna \\
\hline 3 & RSU Eka Hospital & Tingkat Paripurna \\
\hline 4 & RSU Islam Ibnu Sina & Tingkat Paripurna \\
\hline 5 & RSU Awal Bros Panam & Tingkat Paripurna \\
\hline 6 & RSU Syafira & Tingkat Paripurna \\
\hline 7 & RSU Prima Hospital & Tingkat Paripurna \\
\hline 8 & RS Ibu dan Anak Zainab & Tingkat Utama \\
\hline 9 & RSU Bina Kasih & Lulus Perdana \\
\hline 10 & RSU Khusus Mata SMEC Pekanbaru & Lulus Perdana \\
\hline 11 & RSU TNI AU-LANUD Roesmin Nurjadin & Lulus Perdana \\
\hline 12 & RSU Bhayangkara Pekanbaru Polda Riau & Lulus Perdana \\
\hline 13 & RSU Prof Dr Tabrani & Lulus Perdana \\
\hline
\end{tabular}

Sumber: Data olahan sekunder, tahun 2018 
Melia, Muhni \& Pamuji, perbandingan pengaruh kinerja manajemen mutu, manajemen pemasaran dan audit internal terhadap ....

\section{e. Responden}

Total sampel yang digunakan ada 26 (dua puluh enam) rumah sakit masing-masing 3 (tiga) orang responden, yaitu:
a. Kepala Manajemen Mutu, atau anggota
b. Kepala Manajemen Pemasaran, atau anggota
c. Kepala Audit Internal, atau anggota

Sehingga jumlah sampel yang digunakan 1 rumah sakit berjumlah 39 (tiga puluh sembilan) orang responden $\mathrm{x}$ 2 (dua) rumah sakit sebanyak 78 (tujuh puluh delapan) orang responden. Berikut rincian data tabel 3.5 tentang jumlah responden yang dijadikan sampel penelitian, yaitu:

Tabel 3.5

Jumlah Responden

\begin{tabular}{|c|c|c|c|c|}
\hline No & Responden & $\begin{array}{c}\text { Rumah Sakit } \\
\text { di Kota Palembang }\end{array}$ & $\begin{array}{c}\text { Rumah Sakit } \\
\text { di Kota Pekanbaru }\end{array}$ & $\begin{array}{c}\text { Jumlah } \\
\text { Responden }\end{array}$ \\
\hline 1 & $\begin{array}{l}\text { Kepala Manajemen } \\
\text { Mutu }\end{array}$ & 13 & 13 & 26 \\
\hline 2 & $\begin{array}{l}\text { Kepala Manajemen } \\
\text { Pemasaran }\end{array}$ & 13 & 13 & 26 \\
\hline 3 & $\begin{array}{l}\text { Kepala Audit } \\
\text { Internal }\end{array}$ & 13 & 13 & 26 \\
\hline \multicolumn{2}{|c|}{$\begin{array}{c}\text { Jumlah Responden } \\
\text { (orang) }\end{array}$} & 39 & 39 & 78 \\
\hline
\end{tabular}

Sumber: Data olahan primer, tahun 2018

\section{f. Teknik Analisis Data}

Teknik analisis datanya menggunakan model regresi linear berganda (multiple linear regression). Analisa berganda digunakan untuk mengukur pengaruh antara lebih dari satu variabel independen (variabel bebas) terhadap variabel terikat (variabel dependen). Model yang digunakan adalah sebagai berikut:

$$
\begin{array}{|ll|}
Y_{1} & =a+b_{1} X_{1}+b_{2} X_{2}+b_{3} X_{3}+\varepsilon \\
Y_{2} & =a+b_{1} X_{1}+b_{2} X_{2}+b_{3} X_{3}+\varepsilon
\end{array}
$$

Keterangan :

$\begin{array}{ll}\mathrm{Y}_{1} & =\text { Akreditasi Pelayanan Rumah Sakit Swasta di Palembang } \\ \mathrm{Y}_{2} & =\text { Akreditasi pelayanan Rumah Sakit Swasta di Pekanbaru } \\ \mathrm{X}_{1} & =\text { Manajemen Mutu } \\ \mathrm{X}_{2} & =\text { Manajemen Pemasaran } \\ \mathrm{X}_{3} & =\text { Audit Internal } \\ \mathrm{a} \& \mathrm{~b}_{1} \text { serta } \mathrm{b}_{2} & =\text { Konstanta. } \varepsilon \quad=\text { Error }\end{array}$




\section{g. Uji Beda Paired-Sample T-Test}

Menurut Trihendradi, $\mathrm{C}$ (2013:97-99) Paired- Sampel T- Test adalah dua pengukuran pada subjek yang sama terhadap suatu pengaruh atau perlakuan tertentu. Ukuran sebelum dan sesudah mengalami perlakuan tertentu diukur. Dasar pemilirannya sederhana, apabila suatu perlakuan tidak memberi pengaruh maka perbedaan rata-ratanya adalah nol.

Analisis Paired-Sample T-Test dapat dilakukan dengan langkahlangkah sebagai berikut:

a. Jika nilai probabilitas Asymp. Sig $(0.000)<\alpha(0,05)$ maka Ho ditolak dan Ha diterima.

b. Jika nilai probabilitas Asymp. Sig $(0.000)>\alpha(0,05)$ maka Ho diterima dan Ha ditolak.

Prosedur uji beda PairedSample T-Test pada penelitian ini mengikuti langkah- langkah sebagai berikut:

a. Menentukan hipotesis yang ditentukan dalam pengujian ini, yaitu:

Terdapat perbedaan yang signifikan antara akreditasi pelayanan rumah sakit swasta di Kota Palembang dengan Kota Pekanbaru.

b. Menentukan level of significant sebesar $5 \%$ atau 0,05

c. Menentukan kriteria pengujian, yaitu:

Jika Asymp. Sig $(0.000)<\alpha$

(0.05) maka Ho ditolak yang artinya terdapat perbedaan yang signifikan antara akreditasi pelayanan rumah sakit swasta di Kota Palembang dengan Kota Pekanbaru.

Jika Asymp. Sig $(0.000)<\alpha$

(0.05) maka Ho diterima yang artinya tidak terdapat perbedaan yang signifikan antara akreditasi pelayanan rumah sakit swasta di Kota Palembang dengan Kota Pekanbaru.

d. Penarikan kesimpulan berdasarkan pengujian hipotesis yang telah dilakukan oleh peneliti.

\section{HASIL PENELITIAN DAN PEMBAHASAN}

Hasil Persamaan Regesi berganda untuk kota Palembang $\left(\mathrm{Y}_{1}\right)$ dan kota Pekanbaru $\left(\mathrm{Y}_{2}\right)$ sebagai berikut:

$Y_{1}=1.997+0.116 X_{1}-0.036 X_{2}+$ $0.510 X_{3}+\mathrm{e}$

$Y_{2}=-253+0,237 X_{1}+0,143 X_{2}+$ $0,667 X_{3}+e$

Analisis Paired- Sample T-Test dapat dilakukan dengan langkah-langkah sebagai berikut:

a. Jika nilai probabilitas Asymp. Sig $(0.000)<\alpha(0,05)$ maka Ho ditolak dan Ha diterima.

b. Jika nilai probabilitas Asymp. Sig $(0.000)>\alpha(0,05)$ maka Ho diterima dan Ha ditolak.

Tabel 4.

Hasil Uji Paired Sample T-Test

Paired Samples Test

\begin{tabular}{|c|r|r|}
\hline & df & Sig. (2-tailed) \\
\hline $\begin{array}{c}\text { Pair 1 Akreditasi Palembang - } \\
\text { Akreditasi Pekanbaru }\end{array}$ & 38 & .000 \\
\hline
\end{tabular}


Melia, Muhni \& Pamuji, perbandingan pengaruh kinerja manajemen mutu, manajemen pemasaran dan audit internal terhadap ....

Pembahasan:

Nilai Asymp. Sig/ 2- tailed $(0.000)<\alpha(0.05)$ maka Ho ditolak, Ha diterima yang artinya terdapat perbedaan yang signifikan antara akreditasi pelayanan rumah sakit swasta di Kota Palembang dengan Kota Pekanbaru.

\section{KESIMPULAN DAN}

\section{SARAN Kesimpulan}

Hasil penelitian ini diperoleh kesimpulan bahwa Akreditasi pelayanan rumah sakit swasta di Palembang dan Pekanbaru sudah baik, namun tingkat kepatuhan dari manajemen rumah sakit swasta di Pekanbaru lebih tinggi, karena dari 26 rumah sakit $61,5 \%$ terakreditasi sedangkan dari 28 rumah sakit swasta di Palembang hanya $50 \%$ terakreditasi oleh Komisi Akreditasi Rumah Sakit.

\section{Saran}

a. Diharapkan manajemen rumah sakit berupaya meningkatkan kualitas dan kredibilitas rumah sakitnya agar lebih diterima publik. Karena pada saat sekarang masyarakat bebas menentukan dimana tempat mendapatkan pelayanan kesehatan yang nyaman dan lebih baik.

b. Peneliti berharap penelitian kedepan lebih dikembangkan terhadap rumah sakit pemerintah tentang bagaimana kinerja manajemen mutu, manajemen pemasaran dan audit internal, karena apakah

manajemen rumah sakit telah menggunakan anggaran yang telah disediakan oleh pemerintah daerah dan kota dengan efisen dan efektif.

\section{DAFTAR PUSTAKA}

Bastian, Indra. 2008. Akuntansi Kesehatan. Jakarta: Penerbit Erlangga.

Hakam, Fahmi. 2016. Analisis, Perancangan dan Evaluasi Sistem Informasi Kesehatan. Yogyakarta: Gosyen Publishing.

Hasan, Iqbal. 2008. Pokok- Pokok Materi Statistik 2 (Statistik Inferensif). Jakata. PT Bumi Aksara.
Herjanto, Eddy. 2008. Manajemen Operasi. Edisi 3. Jakarta: Penerbit PT Grasindo.

Jacobs, F Robert dan Chase Richard B. 2015. Manajemen Operasi dan Rantai Pasokkan (Operations and Supply Chain Management). Edisi 14 (1). Jakarta: Penebit Salemba Empat.

Korompis, Grace E.C. 2016. Organisasi dan Manajemen Kesehatan. Jakarta: Penerbit Buku Kedokteran EGC.

Komisi Akreditasi Rumah Sakit (KARS). 2018. Standar Nasional Akreditasi Rumah Sakit (SNARS). Edisi 1. 1 Januari 2018.

Komisi Akreditasi Rumah Sakit. 2018. Daftar Rumah Sakit Terakreditasi. Kars

Accreditation System. diakses pada tanggal 13 September 2018, di http://akreditasi.kars.or.id/accreditatio n/report_accredited.php.

Kotler, Philip dan Keller, Kevin Lane. 2009. Manajemen Pemasaran. Edisi 13 (2). Jakarta: Penerbit Erlangga.

Kusbaryanto. 2010. Peningkatan Mutu Rumah Sakit dengan Akreditasi. Mutiara Medika Jurnal Kedokteran dan Kesehatan. Vol. 10 (1). E-ISSN: 2614- 0101. P-ISSN:1411 8033. Hal 86-89. Universitas Muhammadiyah Yogyakarta.

Peraturan Menteri Kesehatan Republik Indonesia Nomor 82 Tahun 2013. Tentang Sistem Informasi Manajemen Rumah Sakit.

Putri, Dewi Murdiyanti P dan Rachmawati, Nunung. 2018. Antropologi

Kesehatan- Konsep dan Aplikasi Antopologi dalam Kesehatan. Yogyakarta: Pustaka Baru Press.

Satrianegara, M. Faiz. 2014. Organisasi dan Manajemen Pelayanan Kesehatan. 
Journal of Applied Business Administration Vol 2, No 2,September 2018, hlm. 278-293

Jakarta Selatan: Penerbit Salemba Medika.

Sugiyono. 2012. Metode Penelitian Kuantitatif, Kualitatif. Bandung: Penerbit Alfabeta.

Trihendradi, C. 2013. Langkah Mudah Menguasai SPSS 21. Yogyakarta: Penerbit Andi. 